\title{
METASTATIC PROLACTINOMA
}

\section{Case report with immunohistochemical assessment for p53 and ki-67 antigens}

\author{
Paulo S. Crusius', Cassiano M. Forcelini', Adroaldo B. Mallmann', Daniela A. Silveira², \\ Elder Lersch², Cláudio A. Seibert', Marcelo U. Crusius', Charles A. Carazzo', \\ Cassiano U. Crusius ${ }^{1}$, Eduardo Goellner ${ }^{1}$
}

\begin{abstract}
Pituitary carcinomas are rare neoplasms characterized by craniospinal and/or systemic metastases originated from the pituitary. Their histopathology is frequently indistinguishable from that of benign adenomas. The development of markers that better reflect their behavior is desirable. We present the case of a 47 year-old man with a prolactin-secreting macroadenoma who was submitted to surgeries, cranial radiation therapy, and bromocriptine treatment, but evolved to a fatal outcome after the disclosure of intracra nial metastases. Tumor samples underwent p53 and Ki-67 immunohistochemical assessment. p53 was absent in all samples, a rare finding among pituitary carcinomas. Ki-67 proliferative index was $2.80 \%$ in the original tumor, $4.40 \%$ in the relapse, and $4.45 \%$ in the metastasis. The figure in the relapse is higher than the expected for a noninvasive adenoma. In conclusion, p53 staining is not positive in all pituitarycarcinomas. A high Ki-67 proliferative index in a pituitary adenoma might indicate a more aggressive behavior.
\end{abstract}

KEY WORDS: prolactinoma, pituitary carcinoma, metastasis, p53, Ki-67.

\section{P rolactinoma metastático: relato de caso com avaliação imuno-histoquímica para os antígenos p53 e Ki-67}

RESUMO - Carcinomas pituitários são neoplasias raras caracterizadas pela presença de metástases cranioespinhais e/ou sistêmicas originadas da hipófise. Sua histopatologia é freqüentemente indistinguível daquela dos adenomas benignos. $O$ desenvolvimento de marcadores que melhor reflitam o seu comportamento é desejável. Apresentamos o caso de um homem de 47 anos com um macroadenoma secretor de prolactina que foi submetido a procedimentos cirúrgicos, radioterapia e tratamento com bromocriptina, mas que evoluiu para o óbito após o descobrimento de metástases intracranianas. Amostras do tumor foram submetidas à análise imuno-histoquímica para os antígenos p53 e Ki-67. A coloração para p53 foi negativa em todas as amostras, um achado raro entre os carcinomas pituitários. O índice proliferativo Ki-67 foi 2,80\% no tumor original, $4,40 \%$ na recidiva e $4,45 \%$ na metástase. $O$ valor obtido na recidiva é maior que o esperado para um adenoma não-invasor. Concluindo, a coloração para p53 não é positiva em todos os carcinomas pituitários. Um índice proliferativo Ki-67 alto em um adenoma pituitário poderia indicar um comportamento mais agressivo.

PALAVRAS-CHAVE: prolactinoma, carcinoma pituitário, metástase, p53, Ki-67.

The prevalence of clinically overt pituitary tumors is around $0.02 \%$ of the population 1 . Most are $\mathrm{m}$ i c roadenomas $(<10 \mathrm{~mm})$, exhibit benign behavior, and produce one of the hormones secreted by the normal gland. Relatively few people develop macroadenomas ${ }^{2}$, usually with a benign phenotype, but that can occasionally become aggressive, infiltrating adjacent structures and recurring repeat- edly despite conventional treatment (invasive adenomas) ${ }^{3,4}$. Rarely, adenomas present even more aggressively, developing intracranial and/or extracranial metastases (pituitary carcinomas). The presence of tumor tissue not contiguous with sella turc i$\mathrm{ca}$ is a condition recquired for diagnosis of a pituitary carcinoma ${ }^{5}$. Its prevalence is estimated around $0.1-0.2 \%$ of all cases of neoplasms of this gland ${ }^{6}$.

${ }^{1}$ Institute of Neurology and Neurosurgery, Passo Fundo RS, Brazil; ${ }^{2}$ D e partment of Pathology, Hospital São Vicente de Paulo, Passo Fundo RS, Brazil

Received 1 February 2005, received in final form 29 April 2005. Accepted 31 May 2005.

Dr. Cassiano Mateus Forcelini - Rua Paissandu 1644/302 - 99010-120 Passo Fundo RS - Brasil. E-mail: cassianoforcelini@brturbo.com.br, neurocirurgia@hsvp.com.br 
Few more than 140 cases of pituitary carcinomas have been reported in the literature ${ }^{7}, 30 \%$ of them represented by prolactin-secreting tumors ${ }^{8}$.

The etiology of pituitary carcinomas is poorly understood and their histology is generally indistinguishable from that of benign adenomas ${ }^{9-11}$. Such factors added to the poor response of such neoplasms to cytotoxic chemotherapy and their fatal outcome $\mathrm{e}^{7,11-13}$ place a challenge towards more precocious diagnosis or suspicion of aggressive behavior $^{13}$. Survival after documentation of metastatic disease is poor; $66 \%$ of patients die within 1 year 7 . It has recently been proposed that markers of ag$g$ ressiveness other than standard histology better reflect the behavior of metastatic pituitary adenomas $^{10,11,14}$. Immunohistochemical stainings for the expression of the protein produced by mutated p53 gene and for Ki-67 (MIB-1) index of cellular proliferation have been suggested as the most promising of those markers ${ }^{10,11}$. However, it remains a theoretical issue whether such immunohistochemical analysis could identify a trend for local invasion or metastatic dissemination when applied to patients with macroadenomas.

\section{CASE}

A 47-year-old white man initiated with recurrent episodes of dizziness and vomiting in 1994. Some months later a moderate sustained fronto-temporal headache, drowsiness, and a defect on the visual fields have appeared. Further health problems were smoking, obesity, hyperlipidemia, and erectile dysfunction of recent onset. On March 1995 a neurosurgeon ordered a computed tomography (CT scan) of the head that exhibited a slight brain atrophy and a space-occupying lesion in sella turcica with $2.5 \mathrm{~cm}$ on its largest diameter, invading suprasell ar cistern (Fig 1). Serum prolactin level was higher than 3,000 $\mathrm{ng} / \mathrm{ml}$ (Table 1), and the rest of his endocrinal profile was not evaluated at that time. The patient was submitted to a surgical intervention through transsphenoidal approach on April 1995. Histopathological examination confirmed a pituitary adenoma. The prolactin dropped after surgeny (on the second day it was $634.4 \mathrm{ng} / \mathrm{ml}$ ) accompanied by the gradual abatement of the symptoms.

On November 1995 a new CT scan demonstrated a tumoral relapse with $1.7 \mathrm{~cm}$ on its larger diameter, still invading suprasellar cistern. Further CT scans performed 9 and 23 months later evidenced little additional growth. At the end of 1997 the patient looked for assistance by our group. He was still complaining about visual difficulty. Examination of the visual fields showed upper bitemporal quadrantanoptic defect. The serum prolactin level was $2,717 \mathrm{ng} / \mathrm{ml}$ (Table). A new surgical procedure was undertaken, this turn by transcranial approach (November 1997). Even though the normalization of the visu- al fields and a great fall in serum prolactin level have happened, the latter did not return to normal range.

On March 1998 a tumoral mass with a slight suprasellar prominence was again manifest on a CT scan, and serum prolactin level raised up to $1,025 \mathrm{ng} / \mathrm{ml}$. The patient was then referred to radiation theraphy, and received 50 Gy of external beam radiation in 35 fractions to sella throughout 40 days. Some months later (August 1999) remarkable decrease of tumoral dimensions on a new CT scan and of serum prolactin levels was evident (Table). A magnetic resonance imaging (MRI) scan of brain and pituitary gland perfo rmed on June 2000 comproved the reduction in tumor size: there was just a small intrasellar spot that had high signal on $\mathrm{T} 2$ and was less contrast-enhancing than the rest of the gland, a finding that was interpreted as a surgical sequel or a small persistent tumor.

Since 1999 treatment with bromocriptine and hormone replacement (thyroxine, prednisone, testosterone, and vasopressin) were carried out, the latter due to a hormonal pattern of panhypopituitarism. Adverse effects (nausea, stomacache) attributed to the increasing daily doses of bromocriptine employed since 2000 made the patient unwilling to accept the therapy. From May to August 2000 he was submitted to a trial with carbegoline $1 \mathrm{mg}$ a week, but serum prolactin level still rose (from $230.4 \mathrm{ng} / \mathrm{ml}$ to $413.0 \mathrm{ng} / \mathrm{ml}$ ). On October 2000 he refused the ret u rnto high doses of bromocriptine proposed by medical staff (17.5 mg a day) and quit accompaniment. Even so, he kept the use of hormone replacement and a low daily dose of bromocriptine $(5 \mathrm{mg}$ ).

On April 2001 the patient started to feel an intense pain on lumbar region with spread to the posterior aspect on the right lower limb, what led him to consult an orthopedist. A CT scan of lumbar spine showed an image suggestive of lumbar intervertebral disk prolapse on L5S1 level. Surgical decompression was undertaken and the disk prolapse was confirmed and excised. However, dur-

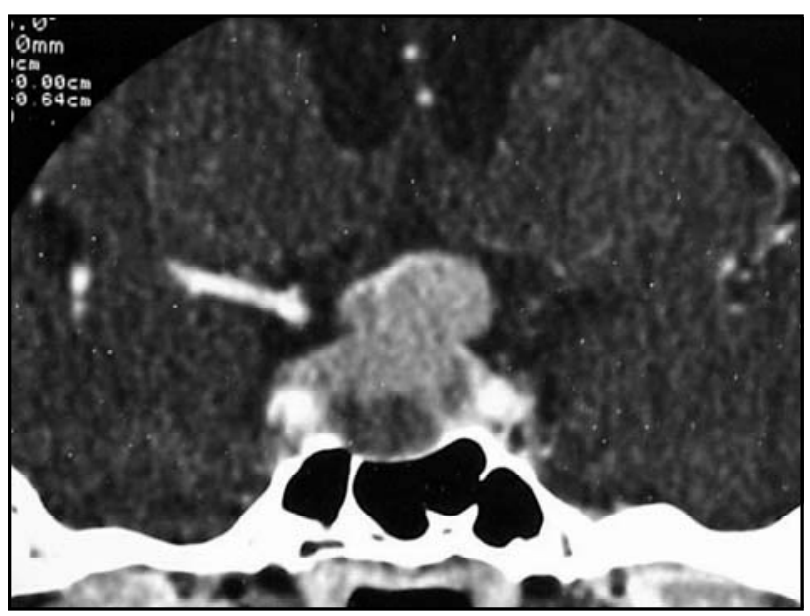

Fig 1. A computed tomography scan of pituitary gland performed on March 1995 exhibiting a space-occupying lesion in sella turcica, invading suprasellar cistern. 
Table. Serum prolactin levels during the evolution of the present case.

\begin{tabular}{lll}
\hline Date & Serum levels $(\mathrm{ng} / \mathrm{ml})^{*}$ & Events \\
\hline April 1995 & $>3,000.0$ & Before 1st surgery \\
May 1995 & 634.4 & After 1st surgery \\
September 1997 & $2,717.0$ & Before 2nd surgery \\
March 1998 & $1,025.0$ & Before radiation therapy \\
May 1999 & 160.6 & After radiation therapy; beginning of bromocriptine \\
June 1999 & 195.2 & \\
December 1999 & 274.0 & \\
April 2000 & 213.4 & Normal brain MRI scan; carbegoline trial \\
May 2000 & 230.4 & \\
August 2000 & 413.0 & Lost of follow-up \\
October 2000 & 548.5 & \\
November 2000 & 844.2 & \\
February 2001 & $1,208.1$ & Before 3rd surgery; cardiac arrest \\
April 2001 & $2,327.6$ &
\end{tabular}

\footnotetext{
*Normal range: (Men) 2.0 to 14.5 . MRI: magnetic ressonance imaging.
}

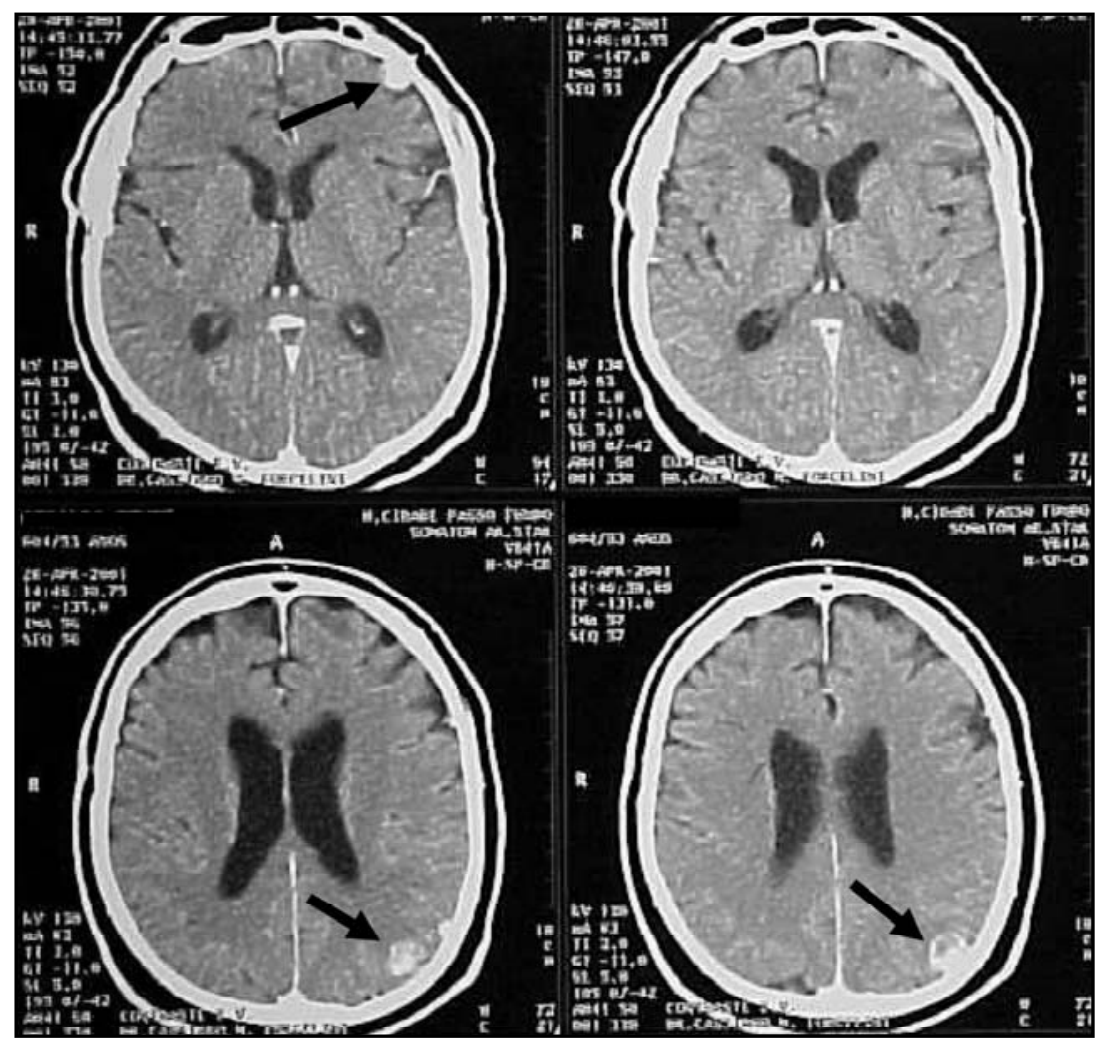

Fig 2. A computed tomography scan of the head performed on April 2001 showing multiple hyperintense lesions with slight contrast enhancement scattered on left ce rebral hemisphere convexity.

ing the procedurethe patient suffered cardiac arrhythmia followed by cardiac arrest that required more than 20 minutes to be reversed. After that, he exhibited an anoxic-ischemic encephalopathy: bilateral Babinski's sign, limb withdrawal to pain, no verbal response, spontaneous eye openning, no evident brain stem damage, and myoclonic jerks in limbs and face. Neurological accompaniment by our staff was then solicited. A CT scan of the head disclosed a surprising finding: multiple hyperintense lesions with slight contrast enhancement scattered on left cerebral hemisphere convexity (Fig 2). No evident tumor in sella or parasellar region was detected.

In the following days a MRI scan of brain and pituitary gland confirmed the presence of the lesions and absence of a sellar mass. A biopsy of one of the meningeal tumors revealed a pituitary adenoma. The contemporary serum prolactin level was $2,373.0 \mathrm{ng} / \mathrm{ml}$ (Table). Evolution was unfavourable, with installation of pneumonia and renal insufficiency. Cardiovascular status remained critical, without evidence of myocardial infarc- 


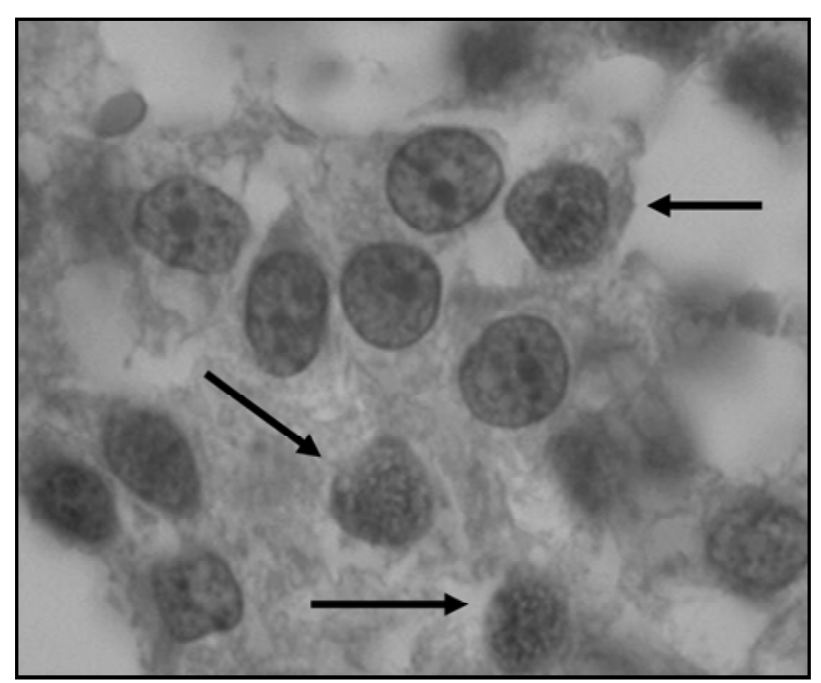

Fig 3. Positiveness for MIB-1 on immunostaining isrepresented by some brown-colored nuclei (metastasis, magnification $X 400$ ).

tion. The patient died 8 days after the surgical intervention. Autopsy was not performed.

Histopathological assessment - Tumor samples obtained from the three surgical interventions (transsphenoidal approach of the original tumor in 1995; transcranial excision of tumor relapse in 1997; biopsy of meningeal metastasis in 2001) were routinely analysed and compared to control tissues. Immunostaining was performed using the streptavidin-biotin-peroxidase method. Primary antibodies were applied to against p53, Ki-67 (MIB-1), prolactin and the growth $(\mathrm{GH})$, thyroid-stimulating $(\mathrm{TSH})$, adrenocorticotropic (ACTH), follicle stimulation (FSH), and luteinizing (LH) hormones.

All tumor samples showed the appearance of a benign pituitary adenoma on standard histopathological examination, with a difuse (solid) pattern constituted by round cells with a predominantly basophilic cytoplasm. Nuclear pleomorphism, cytological atypia, and necrosis we re not detected, while mitotic figures were rare. Immunostaining for pituitary hormones was positive only for the prolactin in the three samples, whereas p53 staining was negative in all of them. Ki-67 staining was detected in all samples with the labeling indices bellow: $2.80 \%$ in original tumor (1995), 4.40\% in relapse (1997), and $4.45 \%$ in metastasis (2001) (Fig 3).

\section{DISCUSSION}

P resent report shares many similarities with previous published cases of pituitary carcinomas. From the initial diagnosis of the macroadenoma to the disclosure of metastatic disease a long interval of seven years has passed. In a series of 15 cases this I atency period ranged from 4 months to 18 years, with the mean of 6.6 years $^{8}$. According to another study, this period is 9.5 years for ACTH-producing lesions and 4.7 years for PRL-secreting tumors ${ }^{7}$. Virtually all pituitary carcinomas arose from macroadenomas $^{8,11}$ and most were submitted to one and, in many times, two surgical approaches and radiation therapy years before appearance of metastases. In this setting, the process of origin seems like a malignant transformation ${ }^{11}$. Radiation therapy and surgical interventions are pointed by some authors as possible causes of such change in behavior ${ }^{12,15,16}$. By the way, the patient with the longest latency period (18 years) in that series was the only who did not undego cranial surgery ${ }^{8}$.

A profile of resistance to bromocriptine action denoted by the increase in serum prolactin levels after some months or years of pharmacological treatment is also a common characteristic among metastatic prolactinomas. This may represent a clue for suspition of an aggressive behavior, but is neither a specific nor an early manifestation. By the time of rise in prolactin levels in present case, no metastatic disease was evident on a MRI scan of brain (June 2000). Nevertheless, it became patent on a CT scan ten months later. Immunostaining for pituitary hormones in the present case reinforced diagnosis of prolactinoma. The proportion of hormone-producing tumors among pituitary carcinomas is reported to be around $74 \%$, represented mostly by the prolactin- or ACTH-secreting subtypes ${ }^{8,11}$. In fact, malignant prolactinomas perform $30 \%$ of pituitary carcinomas ${ }^{8}$.

Although histology of metastatic deposits in many cases tends to appear more aggressive than primary tumor ${ }^{11}$, the aspect is commonly indistinguishable from that of benign adenomas ${ }^{10,11,17}$, even on ultrastructural grounds 9 . Traditional histopathological features of malignancy (mitotic figures, nuclear pleomorphism, high cellularity, cytological atypias, presence of necrosis) are uncommon. When mitotic figures are present, they do provide some indication of the behavior and invasive potential of pituitary tumors, but for routine diagnostic purposes, however, discriminating power of this parameter is somewhat limited ${ }^{18}$. This discrepancy between clinical and pathological characteristics has led to a search for markers more informative of the behavior of pituitary carcinomas. For instance, a myriad of genetic mutations has been reported in such tumors ${ }^{12,19-21}$, but their assessment has shown little, if any, clinical usefulness ${ }^{12}$. Besides, several biochemical and histopathological markers have recently been investigated in order to evalu- 
ate the etiopathology of pituitary carcinomas, but still without conclusive results ${ }^{22-32}$.

In the last years an increasing amount of data about immunohistochemical assessment of the expression for mutant protein of p53 gene and for Ki67 (MIB-1) antigen expressed during cellular proliferation has suggested that such immunostainings may be promising markers of a malignant behavior in pituitary neoplasms. p53 is a nuclear protein encoded by a gene located on chromossome 17p13.1, a tumor suppressor gene ${ }^{7}$. Its alteration makes it act as a dominant oncogene. The gene is found mutated and/or deleted in a wide range of tumors, predominantly malignant ${ }^{14}$. In normal tissues wild-type $\mathrm{p} 53$ protein cannot be detected by immunohistochemistrydue to short half-life and rapid turnover. However, once mutated, stabilized $p$ rotein can be detected by antibodies ${ }^{10,14}$. Studies about correlation between immunohistochemical data with actual mutations in p53 gene have rendered conflicting results, suggesting that immunostaining may not represent the real genetic status $^{10,17,18}$. Despite the issue, the value of positiveness for p53 as a useful way for better representing the phenotype of pituitary tumors has been emphasized ${ }^{10,14}$. An evaluation of 70 pituitary adenomas rendered a pro $p$ o rtion of $p 53$ positive cases among noninvasive adenomas, invasive adenomas and carcinomas of $0 \%, 15.2 \%$, and $100 \%$ respectively 10 . Figures not so dramatic but also suggestive of an association of positiveness for p53 with an aggressive trend were produced ${ }^{14}$. It is discussed whether technical differences could be responsible for variable findings among studies ${ }^{10,33}$. $\mathrm{Nevertheless,} \mathrm{absent} \mathrm{p53} \mathrm{immunostaining} \mathrm{in} \mathrm{pitu-}$ itary carcinomas was recently reported ${ }^{26,32,34}$, a finding also encountered by our group. This suggests that this method is not so sensitive as first imagined.

New histochemical methods of growth fraction determination were developed in last decades in o rder to provide rapid and cheap means of gauging pituitary tumor behavior. One of the most promising of these is detection of $\mathrm{Ki}-67$ antigen, a p roliferation marker that is selectively expressed during G1, S1, G2, and $M$ phases of cell cycle ${ }^{8,18,31,35}$. It can be assessed through the use of the MIB-1 immunostaining, the antibody against the $\mathrm{Ki}-67$ for the paraffin preparations ${ }^{8,11}$. Studies with MIB-1 have revealed that growth fraction of pituitary tumors is low, with indices generally lower than $5 \%{ }^{11}$. Vi rtually all noninvasive adenomas have a growth fraction of less than $3 \%^{11}$. On the other hand, growth fractions are significantly higher among invasi- ve adenomas, and the highest among pituitary carcinomas, when compared to noninvasive adenomas $(4.7 \%, 11.9 \% \text {, and } 1.4 \% \text {, respectively })^{36}$. Indeed, p53positive pituitary tumors (carcinomas and invasive adenomas) had four times higher indices of MIB1 staining than $p 53$-negative neoplasms ${ }^{10}$. The present case shows a MIB-1 index of $2.80 \%$ in original tumor (1995). However, the figure reached $4.40 \%$ in the relapse (1997) and $4.45 \%$ in the metastatic deposit (2001). That is, there was an unexpected rise between first and second surgeries.

Even though such immunohistochemical stainings could better reflect the behavior of pituitary tumors, it remains unknown wheter those markers could lead to an early suspicion of a malignant transformation when applied to patients with macroadenomas. In case this hypothesis is true, positiveness for $\mathrm{p} 53$ or a high MIB-1 index could serve as signs indicating that a macroadenoma is likely to metastatize or become locally aggressive. For instance, the present case shows a higher than expected MIB-1 index at the second intervention, when neither evidence of local invasion nor of metastatic dissemination were present. Some authors consider the concept that primary tumors that exhibit mitotic activity, an increased (> 3\%) MIB-1 labeling index, and/or p53 immunoreactivity should be termed "atypical adenomas" to denote their aggre ssive potential and the possibility of future malignant transformation ${ }^{35}$. Would it indicate the need of a more aggressive tretment, like chemotherapy, to prevent local invasion or metastases? This question could be answered with aid of prospective studies that assess p53 and MIB- 1 stainings ro utinely in every surgical intervention for pituitary adenomas, since all knowledge about the issue is based on re trospective and, perhaps, selected cases.

In conclusion, pituitary carcinomas re $\mathrm{p}$ resent a $r$ a re neoplasm with fatal outcome, for which p53 and MIB-1 immunostainings emerged as clues for a better assessment of tumor behavior. However, not all pituitary carcinomas show positiveness for p53. On the other hand, a higher than expected Ki-67 proliferative index in a pituitary adenoma might alert to the possibility of a more aggressive behavior.

Aknowledgements - The authors wish to thank the Institute of Pathology of Passo Fundo (Passo Fundo) and the Department of Pathology of Moinhos de Vento Hospital (Porto Alegre) for the courtesy of ceding tumor samples for the present study, and the patient's family who authorized the publication of this case report. 


\section{REFERENCES}

1. Faglia G. Epidemiology and pathogenesis of pituitary adenomas. Acta Endocrionol (Copenh) 1993;129:1-5.

2. Gollard R, Kosty M, Cheney C, Copeland B, Bordin G. Prolactin-secre ting pituitary carcinoma with implants in the cheek pouch and metastases to the ovaries: a case report and literature review. Cancer 1995; 76:1814-1820.

3. Price PA. Cytotoxic chemotheraphy for aggressive pituitary tumours. In Grosman A (ed). Clinical endocrinology. Oxford: Blackwell, 1992;235-237.

4. Shelman WR, Laws ER, Scheithauer BW, Carpenter SM. The occurence of dural invasion in pituitary adenomas. J Neurosu rg1986;64:402-407.

5. Scheithauer BW, Kovacs KT, Laws ER, Randall RV. Pathology of invasive pituitary tumours with special reference to functional classification. J Neurosurg 1986;65:733-744.

6. Beauchesne P, Trouillas J, Brral F, Brunon J. Gonadotropic pituitary carcinoma: case report. Neurosurgery 1995;37:810-816.

7. Ragel BT, Couldwell WT. Pituitary carcinoma: a review of the literature. Neurosurg Focus 2004;16:E7.

8. Pernicone PJ, Scheithauer BW, Sebo TJ, et al. Pituitary carcinoma: a clinicopathological study of 15 cases. Cancer 1997;79:804-812.

9. Scheithauer BW, Fereidooni F, Horvath E, et al. Pituitary carcinoma: an ultrastruxtural study of eleven cases. Ultrastruct Pathol 2001;25:227-242.

10. Thapar K, Scheithauer BW, Kovacs K, Pernicone PJ, Laws ER Jr. p53 expression in pituitary adenomas and carcinomas: correlation with invasiveness and tumor growth fraction [experimental studies]. Neurosurgery 1996;38:765-771.

11. Thapar K, Kovacs K. Neoplasms of the sellar region. In Bigner DD, McLendon RE, Bruner JM (eds). Russel and Rubinstein's pathology of tumors of the nervous system, 6.Ed. London: Arnold, 1998:561-677.

12. Hu rel SJ, Harris PE, McNicol AM, Foster S, Kelly WF, Baylis P. Metastatic prolactinoma: effect of octreotide, carbegoline, carboplatin and etoposide; immunocy tochemical analysis of proto-oncogene expression. J Clin Endocrinol Metab 1997;82:2962-2965.

13. Kaltsas GA, Mukherjee JJ, Plowman PN, Monson JP, Grossman AB, Besser GM. The role of cytotoxic chemotherapy in the management of a g g ressive and malignant pituitary tumors. J Clin Endocrinol Metabol 1998;83:4233-4238.

14. Buckley N, Bates AS, Broome JC, et al. p53 protein accumulates in Cushings adenomas and invasive non-functional adenomas. J Clin Endocrinol Metabol 1994;79:1513-1516.

15. Mountcastle RB, Roof BS, Mayfield RK, Morde DB, Sagel J, Bigg PJ. Case report: pituitary adenocarcinoma in an acromegalic patient: response to bromocriptine and pituitary testing: a review of the literature on 36 cases of pituitary carcinoma. Am J Med Sci 1989;298:109-118.

16. Papotti M, Limone P, Riva C, Gatti G, Bussolati G. Malignant evolution of an ACTH-p roducing pituitary tumor treated with intrasellar implantation of 90Y: case report and review of the literature. Appl Pathol 1984;2:10-21.

17. Bayindir C, Balak N, Gazioglu N. Prolactin-secreting carcinoma of the pituitary: clinicopathological and immunohistochemical study of a case with intracranial and intraspinal dissemination. Br J Neurosurg 1997; 11:350-355.

18. Thapar K, Yamada Y, Scheithauer B, Kovacs K, Yamada S, Stefaneanu L. Assessment of mitotic activity in pituitary adenomas and carcinomas. Endocr Pathol 1996;7:215-221.
19. Rickert $\mathrm{CH}$, Scheithauer BW, Paulus W. Chromossomal aberrations in pituitary carcinoma metastases. Acta Neuropathol 2001;102:117-120.

20. Yu R, Melmed S. Oncogene activation in pituitary tumors. Brain Pathol 2001;11:328-341.

21. Rickert CH, Scheithauer BW, Paulus W. Chromosomal aberrations in pituitary carcinoma metastases. Acta Neuropathol 2001;102:117-120.

22. Kong YG, Ren ZY, Su CB, Wang RZ, Ma WB, Lian W. Elevated soluble epidermal growth factor receptor level in pituitary adenoma and carcinoma. Chin Med Sci J 2004;19:199-202.

23. Onguru O, Scheithauer BW, Kovacs K, et al. Analysis of epidermal growth factor receptor and activated epidermal growth factor receptor expression in pituitary adenomas and carcinomas. Mod Pathol 2004; 17:772-780.

24. Onguru O, Scheithauer BW, Kovacs K, et al. Analysis of Cox-2 and thromboxane synthase expression in pituitary adenomas and carcinomas. Endocr Pathol 2004;15:17-27.

25. Mulla A, Christian HC, Solito E, Mendoza N, Morris JF, Buckingham JC. Expression, subcellular localization and phosphorylation status of annexins 1 and 5 in human pituitary adenomas and growth hormonesecreting carcinoma. Clin Endocrinol (Oxf) 2004;60:107-119.

26. Roncaroli F, Nose V, Scheithauer BW et al. Gonadotropic pituitary carcinoma: HER-2/neu expression and gene amplification: report of two cases. J Neurosurg 2003;99:402-408.

27. Vidal S, Horvath E, Kovacs K, Kuroki T, Lloyd RV, Scheithauer BW.Expression of hypoxia-inducible factor-1alpha (HIF-1alpha) in pituitary tumours. Histol Histopathol 2003;18:679-686.

28. Jin L, Zhang S, Bayliss J, et al. Chromogranin a processing in human pituitary adenomas and carcinomas: analysis with region-specific antibodies. Endocr Pathol 2003;14:37-48.

29. Trouillas J, Daniel L, Guigard MP, et al. Polysialylated neural cell adhesion molecules expressed in human pituitary tumors and related to extrasellar invasion. J Neurosurg 2003;98:1084-1093.

30. Riss D, Jin L, Qian X, et al. Differential expression of galectin-3 in pituitary tumors. Cancer Res 2003;63:2251-2255.

31. Lubke D, Saeger W, Ludecke DK. Proliferation markers and EGF in ACTH-secreting adenomas and carcinomas of the pituitary. Endocr Pathol 1995;6:45-55.

32. Nose-Alberti V, Mesquita MI, Martin LC, Kayath MJ. Adrenocorticotropin-producing pituitary carcinoma with expression of c-erbB-2 and high PCNA index: a comparative study with pituitary adenomas and normal pituitary tissues. Endocr Pathol 1998;9:53-62.

33. Levy A, Hall L, Yeudall Wa, Lightman SL. p53 gene mutations in pituitary adenomas: rare events. Clin Endocrinol (Oxf) 1994;41:809-814.

34. Kumar K, Macaulay RJ, Kelly M, Pirlot T. Absent p53 immunohistochemical staining in a pituitary carcinoma. Can J Neurol Sci 2001;28:174-178.

35. Gaffey TA, Scheithauer BW, Lloyd RV, et al. Corticotroph carcinoma of the pituitary: a clinicopathological study. Report of four cases. J Neurosurg 2002;96:352-360.

36. Thapar K, Kovacs K, Scheithauer BW, et al. Proliferative activity and invasiveness among pituitary adenomas ans carcinomas: an analysis using the MIB-1 antibody. Neurosurgery 1996;38:99-107. 